\title{
Pengembangan LKPD Berbasis Discovery Learning Berbantuan Software Tracker Untuk Meningkatkan Pemahaman Konsep Peserta Didik Kelas X SMA Pada Materi Gerak Harmonis Sederhana
}

\author{
Sela Melinia*, Patricia H.M Lubis, Sulistiawati \\ Program Studi Pendidikan Fisika, Universitas PGRI Palembang \\ *Email: sellamelinia02@gmail.com
}

Received: 7 Juli 2021; $\quad$ Accepted: 13 September 2021;

DOI: http://dx.doi.org/10.29303/jpft.v7i2.2782

Published: 22 Oktober 2021

\begin{abstract}
This study aims to produce LKPD based on Discovery Learning assisted by Tracker Software to improve understanding concepts of class $X$ students at SMA Sriguna Palembang those are valid, practical, and have a potential effect on understanding concepts. This study uses a modified Rowntree development model based on formative evaluation. The subjects used in this research are students of class X IPA 2 SMA Sriguna Palembang, as many as 34 students. This research produces: 1) LKPD based on Discovery Learning assisted by Tracker Software which is valid. Based on the research results, the average results of material aspects are $81.33 \%$, learning design aspects are $80 \%$ and language aspects are $80 \%$,2) practicality test results in the one to one stage obtained an average of $93 \%$ with a very practical category, 3) the results of the practicality test at the small group stage obtained an average of $87.62 \%$ with a very practical category, 4) the field test stage obtained the highest $\mathrm{N}$-Gain value by $64.70 \%$ in the high category and the lowest $N$-Gain value is $35.29 \%$ in the medium category.
\end{abstract}

Keywords: LKPD; Discovery Learning; Tracker Software

\section{PENDAHULUAN}

Salah satu kegiatan pembelajaran di sekolah adalah pembelajaran mata pelajaran Fisika. Mata pelajaran Fisika adalah mata pelajaran yang berkaitan erat dengan berbagai macam fenomena atau gejala alam yang terjadi pada kehidupan sehari-hari yang bersifat nyata maupun abstrak (Perdana, et al., 2017). Oleh karena itu pembelajaran Fisika mempersiapkan siswa memiliki kemampuan logika dan kemampuan menggunakan alat ukur dalam proses belajar.

Berdasarkan hasil analisis wawancara dengan guru Fisika di SMA yang menjadi subyek penelitian, permasalahan di sekolah tersebut adalah kurangnya media pembelajaran yang menarik dalam proses pembelajaran. Guru lebih cendrung menggunakan buku cetak dan LKPD yang sudah ada. Guru jarang menggunakan kegiatan pratikum selama proses pembelajaran fisika. Hal ini tentu saja menjadikan siswa sulit memahami materi pelajaran. Hasil wawancara dengan beberapa siswa SMA terlihat bahwa menurut mereka fisika adalah pembelajaran yang sulit karena banyak rumus dan hitunghitungan. Pemahaman konsep peserta didik rendah ketika mereka diberi pertanyaan seputar materi Gerak harmonis sederhana.

Untuk mengatasi permasalahan di atas, maka diperlukan media pembelajaran yang bisa menarik minat peserta didik untuk belajar fisika. Menurut Pratama dan Saregar (2019) bahwa salah satu media yang dapat mengembangkan kemampuan pemahaman konsep siswa adalah LKPD. LKPD adalah media yang dapat dimanfaatkan untuk membantu siklus belajar dan menarik pendapatan siswa dalam pembelajaran (Sari \& Lepiyanto, 2016).

Agar media pembelajaran tersebut lebih menarik maka dibutuhkan bantuan 
suatu perangkat lunak yang lebih aplikatif. Sebagian besar siswa sekarang ini sudah mempunyai Hand phone ( $\mathrm{Hp}$ ) pintar dimana berbagai aplikasi bisa dimasukkan dalam $\mathrm{Hp}$ tersebut. Aplikasi yang di-down load bisa digunakan sebagai perangkat lunak yang membantu media pembelajaran seperti LKPD. Salah satu bentuk aplikasi yang dapat digunakan sebagai media pembelajaran adalah Software Tracker. Menurut Nurohman dalam (Raflesiana, et al. 2019) aplikasi software tracker mampu melakukan pelacakan gerak pada suatu objek dengan menghasilkan berbagai infromasi yang dibutuhkan pada analisis gerak benda yang sangat persisi.

Selain media pembelajaran dan aplikasi yang membantu media pembelajaran tersebut, perlu juga ditentukan bentuk strategi dan model pembelajaran yang digunakan. Model pembelajaran yang dipilih adalah Discovery Learning. Discovery Learning adalah salah satu model pembelajaran yang menekankan pada pemahaman konsep (Nua, et al., 2018). Menurut Nomleni \& Manu (2018) pemahaman konsep merupakan hasil belajar peserta didik yang mampu mendefinisikan atau menjelaskan sebagian bahan pelajaran dengan menggunakan kalimat sendiri.

Adapun tujuan dalam penelitian ini adalah untuk menghasilkan LKPD berbasis discovery learning berbantuan software tracker untuk meningkatkan pemahaman konsep peserta didik kelas X SMA pada materi getaran harmonik sederhana yang valid, praktis, dan memiliki efek potensial terhadap pemahaman konsep peserta didik.

Penelitian penggunaan aplikasi Software Tracker dalam pembelajaran fisika sudah ada. Penelitian Habibbulloh, dan Madlazim (2014) menerapan aplikasi Software Tracker dalam Pembelajaran Fisika pada materi Konsep Gerak Jatuh Bebas. Agustin, et al.. (2017) memanfaatkan
Software Tracker untuk meningkatkan kemampuan berpikir kritis peserta didik pada materi Implus dan Momentum. Fitriyanto, et al. (2016) menerapkan Software Tracker pada praktikum Kinematika Gerak. Dari jurnal ini terlihat sepanjang penulis pahami bahwa Software Tracker belum pernah diaplikasikan pada materi getaran harmonik sederhana.

\section{METODE PENELITIAN}

Metode penelitian yang digunakan dalam penelitian ini adalah penelitian dan pengembangan (reserch and development/R\&D). Menurut Borg and Gall dalam (Sugiyono 2016:9) penelitian dan pengembangan merupakan metode yang digunakan untuk menghasilkan suatu produk yang valid. Dalam penelitian ini produk yang akan dihasilkan yaitu LKPD berbasis discovery learning berbantuan software tracker pada materi Gerak Harmonis Sederhana.

Model pengembangan yang digunakan yaitu menggunakan model pengembangan Rowntree. Model Rowntree memiliki tiga tahapan yaitu tahap perencanaan, tahap pengembangan, dan tahap evaluasi. Pada tahap evaluasi digunakan model Rowntree yang dimodifikasi menggunakan evaluasi Formatif Tesmer yaitu evaluasi diri (selfevalution), evaluasi ahli (expert review), uji coba satu-satu (one to-one), uji coba kelompok kecil (small group), dan evaluasi uji coba lapangan (field review).

Subjek penelitian ini adalah peserta didik kelas X IPA SMA yang berjumlah 34 orang peserta didik. Adapun pengumpulan data yang digunakan peneliti adalah wawancara, angket, tes, dan observasi.

\section{HASIL DAN PEMBAHASAN Hasil}

Hasil penelitian ini adalah lembar kerja peserta didik (LKPD) berbasis 
discovery learning berbantuan software tracker pada materi getaran harmonis sederhana telah melalui beberapa tahap. Sesuai dengan metode penelitian dan pengembangan Rowntree penelitian ini memiliki tiga tahap, yakni tahap perencanaan, tahap pengembangan (development), dan tahap evaluasi (self evaluation, expert review, one to one, small group, dan field test).

Tahap awal pada penelitian ini adalah perencanaan. Pada tahap perencanaan ini peneliti melakukan analisis kebutuhan peserta didik dengan melakukan wawancara dengan guru dan beberapa peserta didik. Selanjutnya, dilakukan analisis tujuan pembelajaran yaitu mengidentifikasi Kompetensi Dasar (KD), materi pokok, indikator pembelajaran, dan tujuan pembelajaran.

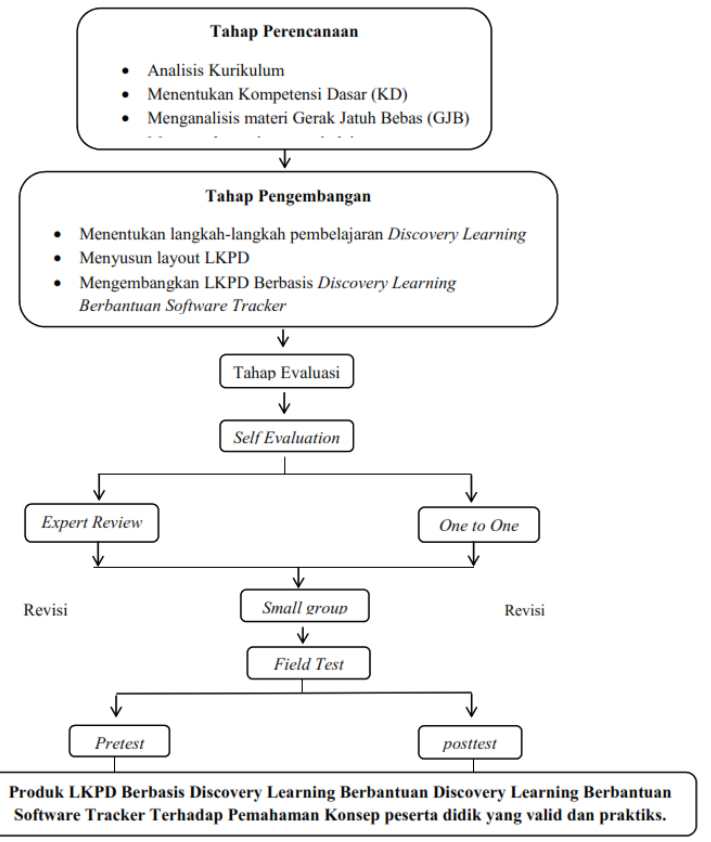

Gambar 1. Prosedur Pengembangan LKPD Berbasis Discovery Learning Berbantuan Software Tracker

Tahap pengembangan LKPD berbasis discovery learning berbantuan software tracker pada materi getaran harmonik sederhana, peneliti melakukan pengembangan topik, penyusun draf serta produksi Prototype yang akan digunakan dalam proses belajar mengajar.

Tahap evaluasi ini digunakan evaluasi formatif Tessmer yang dimulai dari self evalution. Tahap ini peneliti melakukan pengoreksian secara mandiri serta dikonsultasikan kepada dosen pembimbing. Hal ini dilakukan untuk menimalisirkan kekurangan dari LKPD. Adapun hasil dari self evalution yaitu 1) perbaiki kalimat pada petunjuk belajar, 2) perbaiki gambar pada materi dan gambar pada langkah-langkah penggunaan software tracker untuk diperjelas atau gambar sendiri, 3) ACC silahkan validasi.

Tahap expert review bertujuan untuk menghasilkan desainn LKPD berbasis discovery learning berbantuan software tracker. Validasi LKPD ini difokuskan pada tiga aspek diantaranya yaitu aspek materi, aspek desain pembelajaran, dan aspek bahasa yang dinilai langsung oleh ketiga validator. Tahap ini dilaksankan dengan menentukan rata-rata hasil penilaian dari ketiga validator dengan menggunakan skala likert. Hasil rata-rata tersebut dapat dilihat pada gambar 1. Hasil validasi ini disebut prototype 1 .

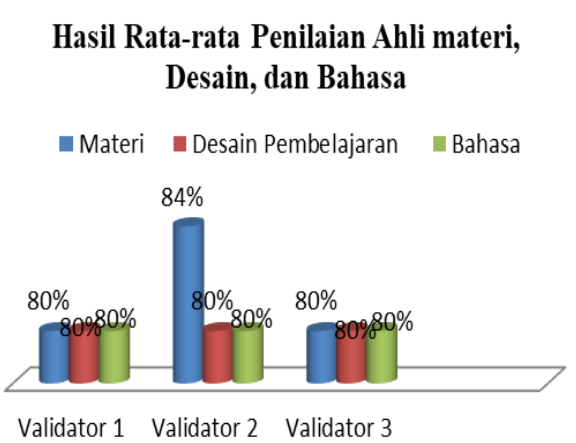

Gambar 2. Grafik Rekapitulasi Hasil Penilain Ketiga Validator

Berdasarkan hasil grafik diatas didapatkan bahwa rata-rata penilaian dari ketiga validator terhadap : 1) aspek materi dengan indikator ketepatan dan kelengkapan 
dan minat mendapatkan nilai rata-rata 4,1 dikategorikan baik dan hasil representase sebesar $81,33 \%$ dikategorikan sangat valid, 2) aspek desain dengan indikator langkahlangkah pembelajaran dan kualitas tampilan atau gambar pembelajaran mendapatkan nilai rata-rata 4 dikategorikan baik dan hasil representase sebesar $80 \%$ dikategorikan valid, 3) aspek bahasa dengan indikator keterbacaan mendapatkan nilai rata-rata 4 dikategorikan baik dan hasil representase sebesar $80 \%$ dikategorikan valid. Hasil validasi dari ketiga validator diperoleh rata-rata $80,66 \%$ yang berarti bahwa LKPD berbasis discovery learning berbantuan software tracker dikategorikan valid.

Tahap one to one ini bertujuan melihat tingkat kepraktisan LKPD berbasis discovery learning berbantuan software tracker dari sudut pandang pengguna melalui pengisian lembar angket angket tanggapan peserta didik. Adapun hasil rata-rata pengisian angket tanggapan peserta didik dapat dilihat pada gambar 3. Berdasarkan gambar 3 diperoleh rata-rata total keseluruhan tanggapan peserta didik dari indikator kualitas isi dan tujuan, kualitas desain, dan kualitas pembelajaran sebesar 93\%. Jadi dapat disimpulkan bahwa prototype 1. LKPD berbasis discovery learning berbantuan software tracker tergolong sangat praktis. Hasil one to one ini disebut prototype 2 .

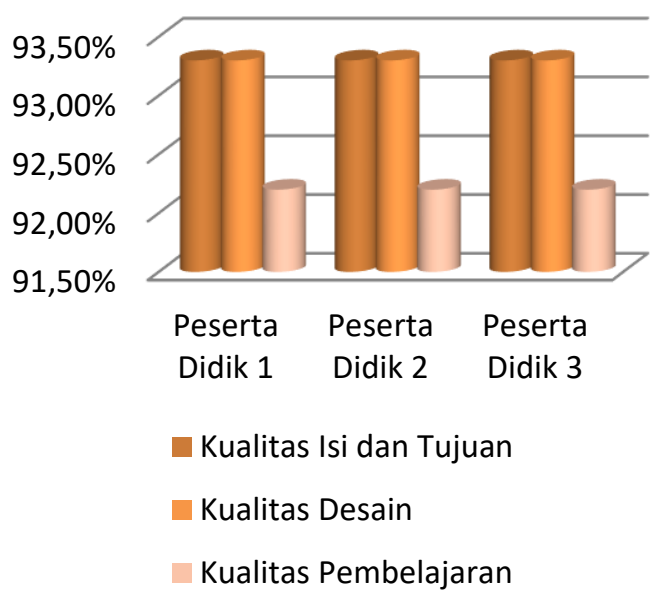

Gambar 3. Grafik Rata-rata Tanggapan Peserta Didik Tahap One to One

Pada tahap small group ini hampir sama dengan one to one evaluation, bedanya peneliti menguji-cobakan prototype 2 LKPD berbasis discovery learning berbantuan software tracker kepada 8 orang peserta didik. Hasil rata-rata tanggapan peserta didik tahap small group pada gambar 5. Berdasarkan gambar 4 didapatkan rata-rata total keseluruhan penilaian angket tanggapan peserta didik tahap small group terhadap penggunaan LKPD berbasis discovery learning berbantuan software tracker pada indikator kualitas isi dan tujuan, kualitas desain, dan kualitas pembelajaran sebesar $87,62 \%$ sehingga dapat disimpulkan bahwa prototype 2 LKPD berbasis discovery learning berbantuan software tracker tergolong sangat praktis. Hasil small group ini disebut prototype 3 .

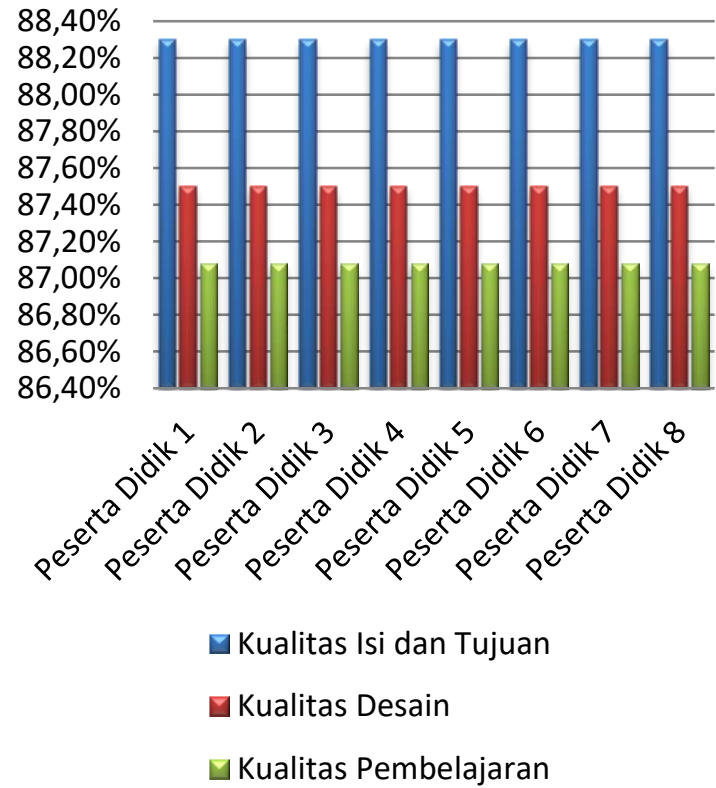

Gambar 4. Hasil Rata-rata Setiap Indikator Tahap Small Group

Tahap field test prototype 3 kemudian diuji-cobakan dengan subjek penelitian berjumlah 34 peserta didik dari kelas X IPA. 
Hasil uji coba pada tahap field test menujukkan bahwa prototype 3 dapat meningkatkan pemahaman konsep peserta didik (table 1) dalam kategori : 1) tinggi sebesar $64,70 \%, 2)$ sedang $35,29 \%$. Nilai rata-rata pretest 35,61 dan nilai rata-rata posttest 79,62.

Tabel 1. Hasil Standar $N$-gain Peningkatan Pemahaman Konsep

\begin{tabular}{cccc}
\hline Batas $N$-gain & $\begin{array}{c}\text { Jumlah } \\
\text { PD }\end{array}$ & Presentase & Kategori \\
\hline$N$-gain $>0,7$ & 22 & $64,70 \%$ & Tinggi \\
\hline $\begin{array}{c}0,7>N \text {-gain } \geq \\
0,3\end{array}$ & 12 & $35,29 \%$ & Sedang \\
\hline$N$-gain $<0,3$ & 0 & $0 \%$ & Rendah \\
\hline
\end{tabular}

Selama kegiatan field test berlangsung dilakukan dengan juga observasi terhadap keaktifan peserta didik selama pembelajaran berlangsung. Adapun hasil rata-rata yang diperoleh dari tahap observasi yaitu dapat dilihat pada gambar 5. Berdasarkan 5 nilai rata-rata karakter peserta didik selama proses pembelajaran : 1) indikator keaktifan rata-rata 4,31 dengan kategori baik, 2) indikator sikap rata-rata 3,74 dengan kategori baik, 3) indikator kerjasama ratarata 3,74 dengan kategori baik, 4) indikator tanggung jawab rata-rata 5 dengan kategori sangat baik, 5) indikator respon rata-rata 3,71 dengan kategori baik.

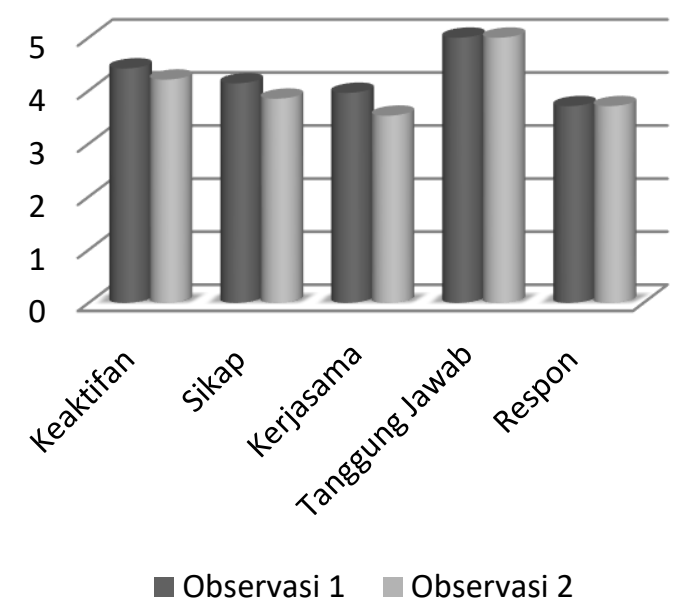

Gambar 5. Hasil rata-rata observasi pada pertemuan pertama dan kedua

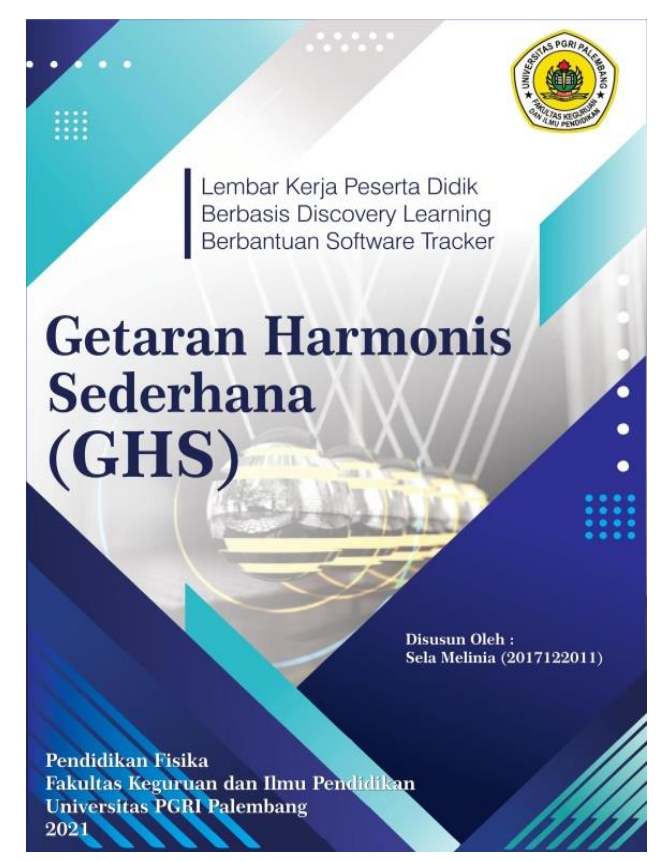

Gambar 6. Cover produk LKPD berbasis Discovery Learning berbantuan Sofware Tracker

\section{Pembahasan}

Tahap expert review rata-rata hasil validasi dikategorikan valid. Kevalidan ini juga dilihat dari sudut pandang hasil tanggapan dari ketiga validator yang positif dari aspek materi, desain dan bahasa. Artinya LKPD yang dihasilkan cukup layak untuk digunakan. Hasil validasi ini disebut prototype 1. Apertha, Zulkardi, \& Yusup, (2018) yang mengembangkan LKPD dengan pengembangan model ADDIE juga melakuan expert review oleh 3 validator. Hasil penilaian ahli yang diperoleh dikategorikan valid, praktis, dan efek potensial berdasarkan penilaian dari aspek kelayakan isi, aspek desain dan aspek bahasa.

Tahap selanjutnya adalah one to one, dimana tiga peserta didik mempelajari LKPD dan dimintai tanggapan dengan mengisi lembar angket.. Hasil tanggapan peserta didik dapat dikategorikan sangat praktis. Artinya LKPD prototype 1 mudah dipahami 
dan menarik untuk dipelajari. Hasil one to one ini disebut prototype 2.

Tahap small group dilakukan dengan menguji-cobakan proses pembelajaran kepada delapan peserta didik dan diberi angket tanggapan terhadap prototype 2 yang telah digunakan. Secara keseluruhan kedelapan orang peserta didik memberikan tanggapan positif dengan nilai kepraktisan kategori sangat praktis. Hasil small group ini disebut prototype 3. Noprinda \& Soleh, (2019) yang mengembangkan LKPD dengan model pengembangan ADDIE juga melakukan tahapan small group dengan hasi dikategorikan sangat baik.

Tahap selanjutnya yaitu field test, dimana proses pembelajaran dilakukan dengan melibatkan 34 orang peserta didik. Selama proses pembelajaran berlangsung. dilakukan juga pengamatan (observasi). Hasil yang didapatkan dari kegiatan pembelajaran menggunakan LKPD berbasis discovery learning berbantuan software tracker berpengaruh baik terhadap aktifitas peserta didik selama pembelajaran berlangsung. Tingkat pemahaman konsep mereka meningkat. Hal ini bisa dilihat dari nilai $\mathrm{N}$-gain dalam kategori tinggi dan sedang. Artinya LKPD berbasis discovery learning berbantuan software tracker yang dihasilkan dapat meningkatkan pemahaman konsep dan keaktifan peserta didik. Munandar, Yusrizal, \& Mustanir, (2015) mengembangkan LKPD dengan model ADDIE juga melakukan field test dengan hasil peningkatan nilai-nilai karakter selama pembelajaran berlangsung.

Penelitian terdahulu lainnya yang juga mendukung hasil yang diperoleh peneliti yaitu penelitian oleh Laksana \& Rabu, (2015) tentang peningkatan aktivitas belajar dan pemahaman konsep peserta didik dengan berbantuan LKS. Hasil dari penilitian ini bahwa penggunaan LKS yang dikembangkan dapat meningkatkan pemahaman konsep peserta didik. Penelitian lainnya dilakukan Apriani, Caswita, \& Asmiati, (2017) menghasilkan produk LKPD berbasis konstruktif yang valid, praktis, dan efektif ditinjau dari pemhaman konsep matematis peserta didik. LKPD yang dihasilkan efektif dilihat dari peningkatan pemahaman konsep peserta didik. Perbedaan dari kedua peneliti terdahulu dengan penelitian yang dilakukan peneliti yaitu penelitian menggunakan penelitian dan pengembangan Borg and Gall.

\section{PENUTUP}

Berdasarkan hasil yang diperoleh peneliti mengenai pengembangan LKPD berbasis discovery learning berbantuan software tracker untuk meningkatkan pemahaman konsep peserta didik kelas $\mathrm{X}$ diperoleh kesimpulan sebagai berikut: 1) LKPD berbasis discovery learning berbantuan software tracker yang dikembangkan dalam penelitian ini dikategorikan valid berdasarkan aspek materi, aspek desain pembelajaran, dan aspek bahasa. 2) LKPD berbasis discovery learning berbantuan software tracker pada materi getaran harmonik sederhana sangat praktis digunakan. 3) LKPD berbasis discovery learning berbantuan software tracker memiliki efek potensial terhadap peningkatan pemahaman konsep dengan kategori tinggi dan sedang. Dilihat dari tes hasil belajar yang memenuhi kategori $74 \%$ (nilai KKM di atas 65)

\section{REFERENSI}

Agustin, F. C., Dirgantara, Y., \& Nuryantini, A. Y. (2017). Pemanfaatan Media Software Tracker Untuk Meningkatkan Kemampuan Berpikir Kritis Peserta Didik Pada Materi Implus dan Momentum di SMKN 1 Soreang. Journal of Teaching and Learning Physics 2, 17-22 
Apertha, F. K., Zulkardi, \& Yusup, M. (2018). Pengembangan LKPD Berbasis Open-Ended Problem Pada Materi Segiempat Kelas VII. Jurnal Pendidikan Matematika, Vol 12 (2) hal 47-62.

Apriani , D., Caswita, \& Asmiati. (2017). Pengembangan LKPD Berbasis Pendekatan Konstruktif untuk Meningkatkan Pemahaman Konsep Matematis. Jurnal Pendidikan Matematika Universitas Lampung, Vol 5 (II) ISSN: 2338-1183.

Fitriyanto, I., \& Sucahyo, I. (2016). Penerapan Soptware Tracker Video Analyzer Pada Praktikum Kinematika Gerak. Jurnal Inovasi Pendidikan Fisika (JIPF), 05(03), 92-97.

Habibbulloh, M., \& Madlazim . (2014). Penerapan Metode Analisis Video Software Tracker dalam Pembelajaran Fisika Konsep Gerak Jatuh Bebas Untuk Meningkatkan Keterampilan Proses Siswa Kelas X SMAN 1 Sooko Mojokerto. Jurnal Pendidikan Fisika dan Aplikasinya (JPFA), Vol 4(1), hal 15-22.

Laksana, D. N., \& Rabu, K. (2015). Pembelajaran Kontekstual Berbantuan LKS dalam Upaya Meningkatkan Pemahaman Konsep IPA dan Aktivitas Belajar Siswa SD . Jurnal Ilmiah Pendidikan, Vol 2 (1) Hal 79-89.

Munandar, H., Yusrizal, \& Mustanir. (2015). Pengembangan Lembar Kerja Peserta Didik (LKPD) Berorientasi Nilai Islami Pada Materi Hidrolis Garam. Jurnal Pendidikan Sains Indonesia, Vol 03(01) hal 27-37.

Nomleni, T. F., \& Manu, N. T. (2018). Pengembangan Media Audio Visual dan Alat Peraga dalam Meningkatkan Pemahaman Konsep dan Pemecahan Masalah. Jurnal Pendidikan dan Kebudayaan, Vol 8 (3), hal 219-230.
Noprinda, C. T., \& Soleh, S. M. (2019). Pengembangan Lembar Kerja Peserta Didik (LKPD) Berbasis Higher Order Thinking Skill (HOTS). Jurnal of Science and Mathematics Education, Vol 02 (2) Hal 168-176.

Nua, M. P., Wahdah, N., \& Mahfud, M. (2018). Pengembangan Lembar Kerja Peserta Didik (LKPD) K-13 Berbasis Discovery Learning Siswa SMA Kelas X Pada Materi Analisis Vektor. Jurnal Nalar Pendidikan, Vol 6(2), Hal 95-104.

Perdana, A., Siswoyo , \& Sunaryo. (2017). Pengembangan Lembar Kerja Siswa Berbasis Discovery Learning Berbantuan Phet Interactive Simulations Pada Materi Hukum Newton . Jurnal Wahana Pendidikan Fisika, Vol (2) 1 Hal 73-79.

Pratama, R. A., \& Saregar, A. (2019). Pengembangan Lembar Kerja Peserta Didik (LKPD) Berbasis Scaffolding Untuk Melatih Pemahaman Konsep. Jurnal of Science and Marthematics Education , 02 (1), Hal 84-97.

Raflesiana, V., Herlina, K., \& Wahyudi, I. (2019). Pengaruh Penggunaan Tracker Pada Pembelajaran Gerak Harmonik Sederhana Berbasis Inkuiri Terbimbing Terhadap Keterampilan Interpretasi Grafik Siswa . Jurnal Ilmiah Penelitian dan Pembelajaran Fisika, Vol. 5 (1) Hal 1-12.

Sugiyono. (2016). Metode Penelitian Pendidikan (Pendekatan Kuantitatif, Kualitatif, dan $R \& D)$. Bandung: ALFABETA,cv.

Yatmi, H. A., Wahyudi , \& Ayub , S. (2019). Pengaruh Model Pembelajaran Generatif Terhadap Kemampuan Berpikir Kritis Fisika Ditinjau Dari Pengetahuan Awal Peserta Didik . Jurnal Pendidikan Fisika dan Teknologi, Vol 5 (2), Hal 287-295. 